\title{
The thanksgiving obelisk dedicated to Dr. Charles Joseph Heidler in Marienbad: a mysterious event in the history of Polish rheumatology and balneology
}

While on holiday in the famous health resort of Marienbad in the Czech Republic (in Czech language: Mariánské Lázně), we found a neoclassical obelisk dedicated to Dr. Charles Joseph Heidler that had been raised in the central park of the city (Skalníkovy sady i.e. the Václav Skalník Park) as a thanksgiving memorial monument by Polish patients in 1858 (Fig. 1). Although memorial plates, monuments, busts and obelisks are common in such places as health resorts, it is rare to find an obelisk erected by anonymous patients representing one nation. Moreover, nothing is known in our history of medicine about this event.

The obelisk (in Czech language: obelisk dr. K. Heidlera) has two almost identical inscriptions. The German inscription: Der Hochverdienter Dr. Karl Josef Heidler Edlen von Heilborn die dankbaren Polen 1858 (To highly meritorious Dr. Charles Joseph Heidler, nobleman of Heilborn, thankful Poles 1858) (Fig. 2). The Latin inscription is a bit longer: CAROLO JOS HEIDLER NOBILI DE HEILBORN MEDICO VIRTUTIS AQUARUM LOCI LABI[LAPI]ORATORI ET NUNCIO AD RECUPERANDAM SALUTEM INDE AB ANNIS QUADRAGINIA INNUMERIS DUCI HUMANISSIMO GRATI POLONI MDCCCLVIII (To Charles Joseph Heidler, nobleman of Heilborn, distinguished physician, meritorious contributor to healing water resort, this stone singing the praises of an excellent director for countless forty years [was raised] by grateful Poles 1858) (Fig. 3). The inscriptions are not well preserved, so the translation should not be considered as literal. The inscriptions clearly suggest that the obelisk was raised by Polish patients to express and immortalize their appreciation for medical care. It gave us the incentive to investigate for more details on Dr. Charles J. Heidler and the obelisk.

In the Municipal Museum of Marienbad, we found a book with a short note on Dr. Charles J. Heidler [1] (Fig. 4). Dr. Charles Joseph Heidler was born on January 26, 1792 in Falkov (now: Sokolov in Czech Republic; before 1948 the Czech name of the city was Falkov nad Ohři, the German name was Falkenau an der Eger). He was the second son of John (Johann) Heydler, a harness maker. He attended the Piarist School in Ostrava, later the secondary school in Pilzen, and studied medicine in Prague, where he graduated in 1818. After graduation, he was appointed to the post of a head physician of the health resort "'healing spring doctor") in Marienbad. There, he spent forty years and contributed significantly to the development of the resort.

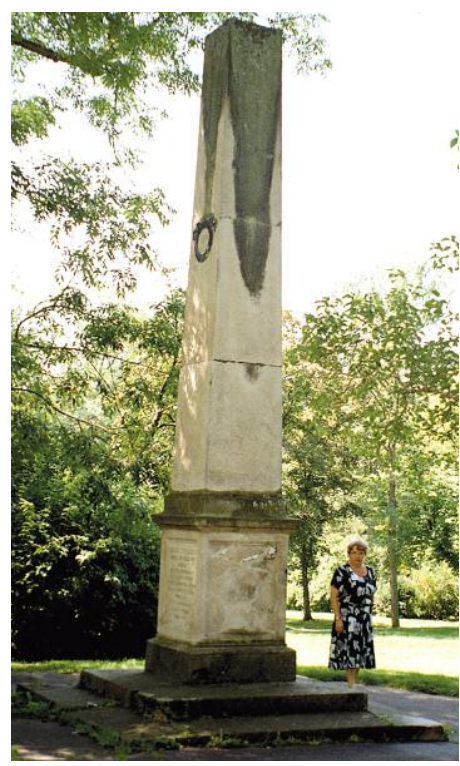

Fig. 1. The obelisk of Dr. Charles Joseph Heidler (photo taken in 2009)

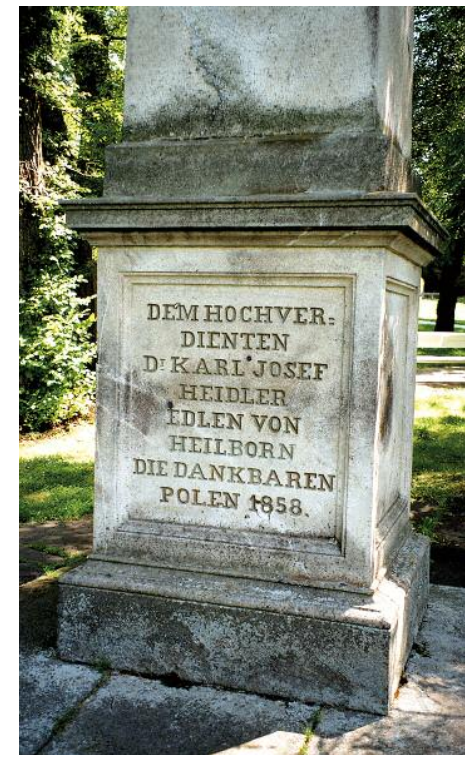

Fig. 2. The German inscription on the obelisk

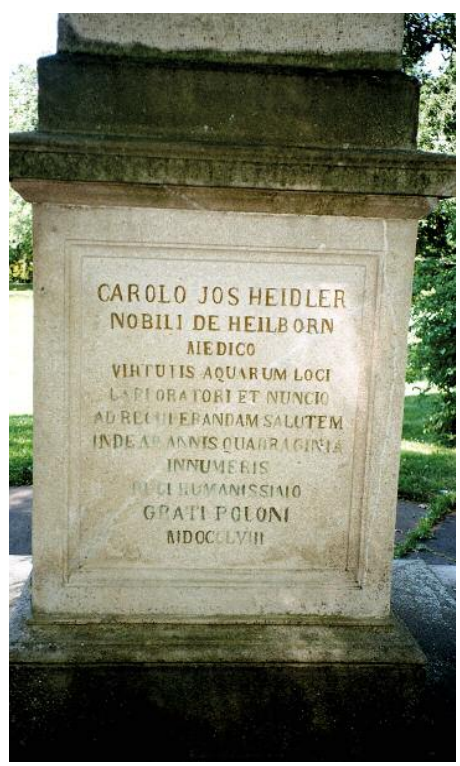

Fig. 3. The Latin inscription on the obelisk 


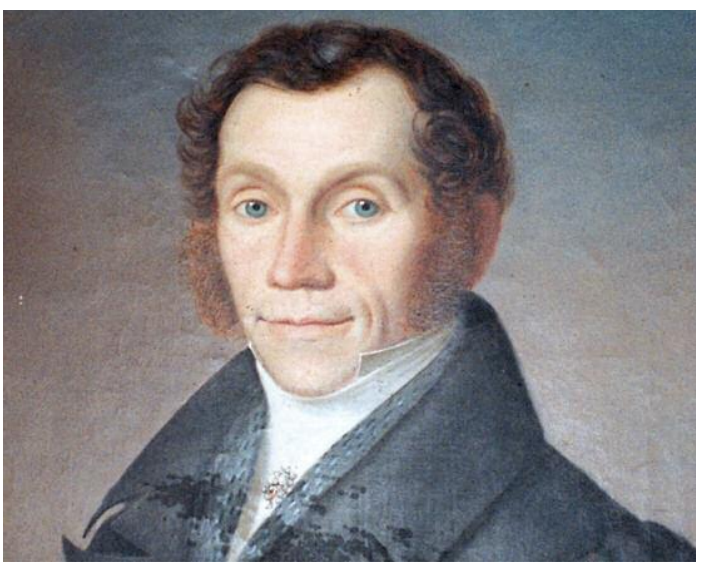

Fig. 4. Dr. Charles Joseph Heidler, a fragment of an oil painting from the collection of the Municipal Museum in Marienbad

For his activity in promotion of the healing springs, he received several distinctions (e.g. the St. Stanislaus Order given by the tsar Nicholas I, the Order of the Red Eagle awarded by the emperor Frederick William III). He was an honorary member of a number of medical societies (including the Cracow Medical Society) and in 1858, the Austrian emperor Franz Joseph I knighted him with the title "from Heilborn" His coat of arms depicted a serpent of Asclepios and a copula of the Cross Spring building in Marienbad. In the same year, Dr. Charles Joseph Heidler resigned from the post of the head physician in Marienbad due to sickness of the eyes and moved to Prague, where he lived in the Vinohrady quarter, and died on May 13, 1866. He is buried in Marienbad in the family grave (Fig. 5). We visited his grave at the Municipal Cemetery. Unfortunately, the grave was squalid, and the cross or sculpture had been stolen. It was sad to see in such bad shape the grave of an individual who had contributed so much to the fame of the city.

In the book mentioned above [1], we found that Dr. Charles Joseph Heidler had been fluent in Czech, German, French, Polish and Russian. During his work in Marienbad he became a physician and friend of a number of famous visitors to the city, including John Wolfgang Goethe. They met for the first time in 1820. Later John Wolfgang Goethe stayed in Marienbad in 1821-1823, and following his leave they exchanged letters until Goethe's death in 1832. John Wolfgang Goethe was a witness of the baptism of Heidler's son because as a Lutheran he could not be the godfather.

All these details are still insufficient to elucidate the origin of "the Polish obelisk". On the Internet, we found a note from the German-speaking edition of the Prague broadcasting. It was a commentary on the Marienbad Chopin Piano Competition. The note contains a mention that Dr. Charles Joseph Heidler was a physician to Frederic Chopin when he visited Marienbad in summer 1836. It was also mentioned that Dr. Heidler was not only a rheumatologist but also an internist. Of course the terms describing the sub-specialties are used in the modern meaning, because the term "internal medicine" was only coined in the $19^{\text {th }}$ century [2]. It is clear that many Poles were receiving spa treatment in Marienbad in the first half of the 19th century, including Adam Mickiewicz, who paid a short visit to the health resort in 1829. The visible traces of their stay are rather limited in Marienbad. A picture of the Black Madonna of Częstochowa with a Polish inscription still can be seen in the Roman Catholic Church "Assumption of Our Lady" in Marienbad. 
Summing up, the obelisk raised in appreciation to Dr. Charles Joseph Heidler is undoubtedly related to Polish history, but details of its foundation, especially the contribution of Dr. Heidler to health care of Polish patients as well as the obelisk founders, still remain unknown.

The authors acknowledge with thanks the valuable help of Mr. Dominik Purchała in translation of the Latin text of the inscription.

Eugeniusz J. Kucharz, Anna Kotulska

\section{References}

1. Somol A, Švandrlík R. Lékařstvi v Mariánských Lázních. Městké muzeum. Mariánské Lázně 2006.

2. Kucharz EJ. Internal medicine: yesterday, today, and tomorrow. I. Origin and development: the historical perspective. Eur J Intern Med 2003; 14: 205-208. 